\title{
Whole-Body Protein Turnover in Preterm Appropriate for Gestational Age and Small for Gestational Age Infants: Comparison of $\left[{ }^{15} \mathrm{~N}\right]$ Glycine and $\left[1-{ }^{13} \mathrm{C}\right]$ Leucine Administered Simultaneously ${ }^{1}$
}

\author{
J. B. VAN GOUDOEVER, E. J. SULKERS, D. HALLIDAY, H. J. DEGENHART, V. P. CARNIELLI, \\ J. L. D. WATTIMENA, AND P. J. J. SAUER \\ Department of Paediatrics [J.B.V.G., E.J.S., H.J.D., V.P.C., J.L.D.W., P.J.J.S.], Academic Hospital \\ Rotterdam/Sophia Children's Hospital, Erasmus University Rotterdam, The Netherlands, and \\ Clinical Research Centre [D.H.], Harrow, London, United Kingdom
}

\begin{abstract}
Measurements of whole-body protein turnover in preterm infants have been made using different stable isotope methods. Large variation in results has been found, which could be due to different clinical conditions and/or the use of different tracers. We studied 14 appropriate for gestational age and nine small for gestational age orally fed preterm infants using $\left[{ }^{15} \mathrm{~N}\right]$ glycine and $\left[1-{ }^{13} \mathrm{C}\right]$ leucine simultaneously, which allowed us to make a comparison of commonly used methods to calculate whole-body protein turnover. Whole-body protein turnover was calculated from ${ }^{15} \mathrm{~N}$ enrichment in urinary ammonia and urea after $\left[{ }^{15} \mathrm{~N}\right]$ glycine administration and from the ${ }^{13} \mathrm{C}$ enrichment in expired $\mathrm{CO}_{2}$ after administration of $\left[1-{ }^{13} \mathrm{C}\right]$ leucine. Enrichment of $\alpha$-ketoisocaproic acid after $\left[1-{ }^{13} \mathrm{C}\right]$ leucine constant infusion was measured as a direct parameter of whole-body protein turnover. Group means for whole-body protein turnover using $\left[{ }^{15} \mathrm{~N}\right]$ glycine or $\left[1-{ }^{13} \mathrm{C}\right]$ leucine ranged from 10 to $14 \mathrm{~g} \cdot \mathrm{kg}^{-1} \cdot \mathrm{d}^{-1}$, except when using the end product method that assumes a correlation
\end{abstract}

between leucine oxidation and total nitrogen excretion. We found very low ${ }^{15} \mathrm{~N}$ enrichment of urinary urea in the majority of small for gestational age infants. These infants also had a lower nitrogen excretion in urine and oxidized less leucine. Nitrogen balance was higher in small for gestational age infants (416 \pm 25 $\left.\mathrm{mg} \cdot \mathrm{kg}^{-1} \cdot \mathrm{d}^{-1}\right)$ compared with appropriate for gestational age infants $\left(374 \pm 41 \mathrm{mg} \cdot \mathrm{kg}^{-1} \cdot \mathrm{d}^{-1}, p=0.003\right) \cdot\left[{ }^{15} \mathrm{~N}\right]$ Glycine does not seem to exchange its label with the body nitrogen pool to a significant degree and is therefore not always suitable as a carrier for ${ }^{15} \mathrm{~N}$ in protein turnover studies in premature infants. (Pediatr Res 37: 381-388, 1995)
Abbreviations
AGA, appropriate for gestational age
SGA, small for gestational age
KICA, ketoisocaproic acid
IRMS, isotopic ratio mass spectrometer

The use of stable isotopes for measuring metabolic processes in vivo has a clear ethical advantage over radioactive isotopes. The nonradioactive character allows their use in pregnancy and in infants. Schoenheimer et al. (1) used stable isotopes to study protein turnover as early as 1939 , but more extensive research has been done since the 1970s, when analytical techniques improved remarkably (2). From then onward, numerous protein turnover studies have been performed using stable isotopes, in adults as well as in children. ${ }^{15} \mathrm{~N}$-labeled amino acids have been favored for many years in preterm infants because of the noninvasive character of the studies. The method allows

Received June 25, 1994; accepted December 8, 1994.

Correspondence: J. B. Van Goudoever, M.D., Ph.D., Sophia Childrens Hospital, Dr. Molewaterplein 60, 3015 GJ Rotterdam, The Netherlands.

Supported by the Netherlands Organization for Scientific Research (NWO) (J.B.V.G.)

${ }^{1}$ Manuscript dedicated to Professor H. K. A. Visser in honor of his retirement. quantification of protein metabolism by measurement of isotope enrichment in an end product of protein catabolism in urine $(3-10)$. $\left[1-{ }^{13} \mathrm{C}\right]$ Leucine, another stable isotopic labeled tracer, has been used for protein studies in preterm neonates more recently, with either the measurement of isotopic enrichment of $\left[1-{ }^{13} \mathrm{C}\right]$ leucine or $\left[{ }^{13} \mathrm{C}\right] \alpha$-KICA in urine $(11,12)$ or plasma (13-17). The different tracers give different results, i.e. for whole-body protein synthesis, rates ranging from 5 $\mathrm{g} \cdot \mathrm{kg}^{-1} \cdot \mathrm{d}^{-1}$ to $26 \mathrm{~g} \cdot \mathrm{kg}^{-1} \cdot \mathrm{d}^{-1}$ have been reported, depending on clinical and experimental conditions $(3,14)$. Studies were performed comparing different tracers and amino acids in adults (18) and in term infants (19) or comparing different amino acids with a similar label $(8,9,20)$. However, to date there are no studies comparing the two most commonly used labeled amino acids, $\left[{ }^{15} \mathrm{~N}\right]$ glycine and $\left[1-{ }^{13} \mathrm{C}\right] \mathrm{leucine}$, in preterm neonates. 
The aim of the present study was to measure the protein turnover rates in orally fed, growing preterm infants using $\left[{ }^{15} \mathrm{~N}\right]$ glycine and $\left[1-{ }^{13} \mathrm{C}\right]$ leucine simultaneously with measurement of enrichment in urinary $\mathrm{NH}_{3}$ and urea, plasma KICA, and expired $\mathrm{CO}_{2}$.

\section{METHODS}

\section{Patients}

Twenty-three stable, growing preterm infants were studied (Table 1). SGA infants were defined as infants with a birth weight more than 2 SD below the mean birth weight for gestation, whereas AGA infants had a birth weight between -2 SD and +2 SD according to the charts of Usher and Mclean (21). Gestational age was determined by maternal history and Ballard score (22). At the time of the study, the infants had been fed for at least 1 wk a preterm formula (Nutricia, Zoetermecr, The Netherlands) and were on full enteral feedings for at least $3 \mathrm{~d}$. As this study is part of a larger study that determines metabolic effects of different encrgy intakes, infants were fed cither a formula containing $80 \mathrm{kcal} / 100 \mathrm{~mL}$ or 67 $\mathrm{kcal} / 100 \mathrm{~mL}$. The protein content of both formulas was equal, $2.2 \mathrm{~g} / 100 \mathrm{~mL}$.

Informed consent from the parents was obtained in all cases, and the study had the approval of the local ethics committee.

\section{Procedures}

Seventy-two-hour nitrogen balance and $\left[{ }^{15} \mathrm{~N}\right]$ glycine wholebody protcin turnover studies were carricd out by collection of urine in 3-h periods using adhesive bags. Urine was put directly in $-20^{\circ} \mathrm{C}$, until analysis. During this period, the fecding was given in a semicontinuous mode (every $15 \mathrm{~min}$ an aliquot of formula) through a nasogastric tube. $\left[{ }^{15} \mathrm{~N}\right]$ Glycine (99 atom\% excess ${ }^{15} \mathrm{~N}, \mathrm{MSD}$, Montreal, Canada) was given in hourly intervals at a dosage of $3 \mathrm{mg}$ of $\left[{ }^{15} \mathrm{~N}\right]$ glycinc $\cdot \mathrm{kg}^{-1} \cdot \mathrm{d}^{-1}$ through the nasogastric tube. Analysis of ${ }^{15} \mathrm{~N}$ enrichment of urinary ammonia and urea and total nitrogen excretion was performed as previously described (10). Visual inspection was used to determine at what time a plateau was reached. The height of the plateau (delta enrichment) was then calculated by substracting the basal enrichment from the mean enrichment of at least five points $(=15 \mathrm{~h})$ at plateau. Nitrogen losses in the stools and through the skin were assumed to be $10 \%$ of the intake (23-26).

On the second day of the $\left[{ }^{15} \mathrm{~N}\right]$ glycine turnover study and the nitrogen balance, a primed constant oral infusion of $\left[1-{ }^{1.3} \mathrm{C}\right]$ leucine (priming dose $2 \mathrm{mg} \cdot \mathrm{kg}^{-1}$, continuous 2 $\mathrm{mg} \cdot \mathrm{kg}^{-1} \cdot \mathrm{h}^{-1}, 99$ atom $\%$ excess ${ }^{13} \mathrm{C}$, Isotech, Miamisburg, $\mathrm{OH}$ ), with an additional priming of the bicarbonate pool with $6.9 \mu \mathrm{mol} / \mathrm{kg}{ }^{13} \mathrm{C}$-labeled sodium bicarbonate (99 atom\% cxcess ${ }^{1.3} \mathrm{C}$, Isotech), was administered for $4 \mathrm{~h}$, using a Harvard infusion pump (M22, Harvard Apparatus Co. Inc., South Natick, MA). The formula was also administered continuously during this period. The infants were nursed in a closed circuit indirect calorimetry incubator during the $\left[1-{ }^{13} \mathrm{C}\right]$ leucine turnover study. Rate of $\mathrm{CO}_{2}$ excretion was measured and expired air was collected before and during the $\left[1-{ }^{13} \mathrm{C}\right]$ leucine admin- istration by passing a sample of air leaving the calorimeter through an all-glass spiral condenser, containing $10 \mathrm{~mL}$ of a fresh $1 \mathrm{M} \mathrm{NaOH}$ solution (27). After liberating $\mathrm{CO}_{2}$ by adding phosphoric acid (85\%) to the solution, the ${ }^{13} \mathrm{CO}_{2}{ }^{12} \mathrm{CO}_{2}$ isotope ratio was measured on an isotope ratio/mass spectrometer in Rotterdam, the Netherlands (SIRA 10, VG, Winsford, Cheshire, UK).

Three blood samples were drawn, one before the start of the study, and two at the end of infusion of $\left[1-{ }^{13} \mathrm{C}\right]$ leucine with a 15 -min interval. Within $15 \mathrm{~min}$, plasma was stored at $-70^{\circ} \mathrm{C}$ until further analysis. The plasma enrichment of KICA was measured by gas chromatography/mass spectrometry with electron impact and selected ion monitoring in Harrow, UK (28).

\section{Calculations}

Required assumptions and the calculations to provide wholebody protein turnover rates by methods frequently reported in the literature are briefly presented. Their relative merits will be discussed later.

There are in gencral two methods to calculate whole-body protein turnover with stable isotope labeled tracers, either using l) enrichment in end products or 2) the direct measurement of the plasma enrichment of an essential amino acid. The former is based on measurement of labeled urea and ammonia as end products of protein metabolism in ${ }^{15} \mathrm{~N}$-tracer studies or on the excretion of ${ }^{13} \mathrm{CO}_{2}$ in expiratory air that is formed at the decarboxylation step as a function of oxidation in ${ }^{13} \mathrm{C}$-tracer studies. Dircct measurement of the dilution of a tracer is usually performed in plasma or urine. Leucine is an essential amino acid that is very often used to assess protein turnover with a direct measurcment in plasma (13).

End products and $\left[{ }^{15}\right.$ N]glycine. Calculation 1 . The measurement of protein turnover using $\left[{ }^{15} \mathrm{~N}\right]$ urea enrichment in urine relies on the concept that there is a single homogenous pool of metabolically active nitrogen in the body (1). ${ }^{15} \mathrm{~N}$ enters this pool by means of ${ }^{15} \mathrm{~N}$-labeled glycine and is freely exchanged between other amino acids. The incorporation of nitrogen into protein and urea is assumed to arise from the same precursor pool.

Nitrogen flux (Q) through this pool is calculated by dividing the amount of administered tracer (d) by the enrichment in urea $\left(\mathrm{IE}_{\text {urca }}\right)(2)$. This simple model is one of the most commonly used methods for studying protein metabolism in preterm neonates.

$$
\mathrm{Q}_{\text {urca }}=\frac{\mathrm{d}}{\mathrm{IE}_{\text {urea }}}
$$

Calculation 2. The measurement of protein turnover using ${ }^{15} \mathrm{~N}$-ammonia enrichment in urine is identical to the one described above, with the only difference of the measurement of enrichment in urinary ammonia instead of urea.

$$
\mathrm{Q}_{\mathrm{NH}_{3}}=\frac{\mathrm{d}}{\mathrm{IE}_{\mathrm{NH}_{3}}}
$$


Calculation 3. The single pool model, as used in calculations 1 and 2, was questioned because of the differences found in enrichment of urea and ammonia $(29,30)$. The next simplest model with the use of end products is the concept of two compartments, from which either urea or ammonia arises. Different mathematical estimates of protein turnover can be obtained using different assumptions regarding flux rates through the compartments and partitioning of the tracer. Assuming an equal partitioning of the tracer dose between the two metabolic compartments, the nitrogen flux equals the arithmetic average of the values for flux obtained individually.

$$
\mathrm{Q}_{\text {arithmatic average }}=\frac{\mathrm{Q}_{\text {ammonia }}+\mathrm{Q}_{\text {urca }}}{2}
$$

Calculation 4. An alternative method to calculate wholebody protein turnover rates based on both urea and ammonia enrichment is by using the harmonic mean. The basic assumption in this calculation is that the nitrogen flux through the pool from which urea is derived is similar to the nitrogen flux through the pool from which ammonia is derived, in equation:

$$
\mathrm{Q}_{\text {harmonic average }}=\frac{2}{\left(1 / \mathrm{Q}_{\text {ammonia }}+1 / \mathrm{Q}_{\text {urea }}\right)} \text {. }
$$

An IRMS is required to measure the ${ }^{15} \mathrm{~N}$ enrichment in urinary ammonia and urea.

End products and $\left[1-{ }^{13}\right.$ C]leucine. Calculation 5. Within the cell, $\left[1-{ }^{13} \mathrm{C}\right]$ leucine is reversibly deaminated to its keto analogue, $\left[{ }^{13} \mathrm{C}\right] \alpha$-KICA. Through decarboxylation of $\left[{ }^{13} \mathrm{C}\right] \alpha$ KICA to isovaleryl-CoA, ${ }^{13} \mathrm{CO}_{2}$ is liberated as a respiratory "end product" of leucine oxidation. The latter step is irreversible.

When using the recovery of label in expiratory air during administration of $\left[1-{ }^{13} \mathrm{C}\right]$ leucine for calculating whole-body protein turnover, one assumes that the ratio of oxidation of leucine $\left(\mathrm{E}_{\mathrm{L}}\right)$ to total body protein oxidation $\left(\mathrm{E}_{\mathrm{N}}\right)$ is equal to the ratio of dietary intake of leucine $\left(\mathrm{I}_{\mathrm{L}}\right)$ to dietary intake of protein $\left(\mathrm{I}_{\mathrm{N}}\right)(18,19)$. In equation:

$$
\frac{E_{L}}{I_{L}}=\frac{E_{N}}{I_{N}}
$$

Total body protein oxidation is measured by the nitrogen excretion $\left(\mathrm{E}_{\mathrm{N}}\right)$. Inasmuch as intake of leucine and total amount of nitrogen in the diet can be calculated from the composition of the formula and the nitrogen excretion can be measured in the urine, the total amount of leucine oxidized can be calculated.

Leucine oxidation also equals the leucine flux times the recovery of label in expiratory air. The equation used for the oxidation is:

$$
\text { Leucine oxidation }=\left(\frac{\mathrm{VCO}_{2} \times \mathrm{IE}_{\mathrm{CO}_{2}}}{\mathrm{I} \times \mathrm{c}}\right) \times \mathrm{Q}
$$

where $\mathrm{VCO}_{2}$ is the rate of $\mathrm{CO}_{2}$ excretion in $\mu \mathrm{mol} \cdot \mathrm{kg}^{-1} \cdot \mathrm{min}^{-1}$ during the $\left[1-{ }^{13} \mathrm{C}\right]$ leucine infusion, $\mathrm{IE}_{\mathrm{CO}_{2}}$ is the isotopic enrichment of expired $\mathrm{CO}_{2}$ at plateau, $\mathrm{I}$ is the $\left[1-{ }^{23} \mathrm{C}\right]$ leucine infusion rate in micromoles of $\left[{ }^{13} \mathrm{C}\right] \cdot \mathrm{kg}^{-1} \cdot \mathrm{min}^{-1}$, and $\mathrm{c}$ is the correction factor for bicarbonate retention calculated from the energy intake (31). If the leucine oxidation is derived from equation 5, and recovery of the label in expiratory air (the first part of equation 6) is measured, an estimate of leucine turnover can be calculated as leucine oxidation divided by recovery of the label. Whole-body protein turnover can be calculated assuming that $590 \mu \mathrm{mol}$ of leucine represent $1 \mathrm{~g}$ of protein (32). Analogous to the measurement of ${ }^{15} \mathrm{~N}$ enrichment in urea or ammonia, the ${ }^{13} \mathrm{C}$ enrichment in expiratory air requires an IRMS as well.

Direct measurement and $\left[1-{ }^{13}\right.$ C]leucine. Calculation 6. With the infusion of $\left[1-{ }^{13} \mathrm{C}\right]$ leucine and the measurement of labeled $\alpha$-KICA, one applies the reciprocal pool model to calculate whole-body protein turnover $(33,34)$. The dilution of the tracer in plasma is an estimate of the turnover of the amino acid, in equation:

$$
\mathrm{Q}=\mathrm{i} \times\left(\frac{\mathrm{E}_{\mathrm{i}}}{\mathrm{E}_{\mathrm{p}}}-1\right) \mu \mathrm{mol} \cdot \mathrm{kg}^{-1} \cdot \mathrm{h}^{-1}
$$

where $\mathrm{i}$ is the $\left[1{ }^{13} \mathrm{C}\right]$ leucine infusion rate $\left(\mu \mathrm{mol} \cdot \mathrm{kg}^{-1} \cdot \mathrm{h}^{-1}\right)$, $\mathrm{E}_{\mathrm{i}}$ is the isotopic enrichment of the $\left[1{ }^{-13} \mathrm{C}\right]$ leucine infused (atom\% excess), and $\mathrm{E}_{\mathrm{p}}$ is the isotopic enrichment of $\alpha$-KICA in plasma. Leucine flux is extrapolated to whole-body protein turnover using again the assumption that $1 \mathrm{~g}$ of protein contains of $590 \mu \mathrm{mol}$ of leucine.

The ${ }^{13} \mathrm{C}$ enrichment of $\alpha$-KICA is measured by a gas chromatograph mass spectrometer. To calculate whole-body protein synthesis and breakdown from whole-body protein turnover the equation used is

$$
\mathrm{Q}=\mathrm{S}+\mathrm{E}=\mathrm{I}+\mathrm{B}
$$

Assuming a constant pool size, nitrogen leaving the pool [for protein synthesis (S) and urinary excretion (E)] should equal nitrogen entering the pool [from dietary intake (I) and from protein breakdown (B)]. With the measurement of total nitrogen excretion and nitrogen intake, both synthesis and breakdown rates can be obtained if the flux $(\mathrm{Q})$ is known. Values for whole body protein are calculated by multiplying the nitrogen data by a factor of 6.25 .

Calculation 7. If one does not want to extrapolate to wholebody protein rates, other terms are used that are directly derived from data obtained by leucine turnover studies. Nonoxidative disposal (NOD, a measure of protein synthesis) and leucine released from proteins (LRP, a measure of protein breakdown) can be calculated according to the following equation:

$$
\mathrm{Q}_{\mathrm{Lcu}}=\mathrm{OX}_{\mathrm{Lcu}}+\mathrm{NOD}_{\mathrm{Lcu}}=\mathrm{I}_{\mathrm{Leu}}+\mathrm{LRP}
$$

Again, these leucine turnover rates can be extrapolated to whole-body protein turnover rates (28). It is not needed to measure nitrogen excretion using this calculation. Both an IRMS and a gas chromatography mass spectrometry are needed to measure the ${ }^{13} \mathrm{C}$ enrichment in expiratory air and the ${ }^{13} \mathrm{C}$ enrichment in $\alpha$-KICA, respectively. 


\section{Statistics}

Data are presented as mean $\pm 1 \mathrm{SD}$. The differences between the estimates of whole-body protein turnover rates with the six different methods were analyzed by one-way analysis of variance with the Bonferroni correction for multiple tests. Correlations between measurements were tested with Spearman rank corrclation tests. Statistical significance was set at a level of $p<0.05$.

\section{RESULTS}

The AGA and SGA infants differed in birth weight, gestational age, and weight at study (Table 1). Because we did not find a significant effect of energy intake on whole-body protein turnover, we did not subdivide the AGA and SGA infants into different energy intake groups. As shown, both energy intake and protein intake were not different between AGA and SGA infants. Glycine and leucine intakes, calculated from the amino acid composition provided by the manufacturer, were $32 \pm 1$ $\mu \mathrm{mol} \cdot \mathrm{kg}^{-1} \cdot \mathrm{h}^{-1}\left(58 \pm 2 \mathrm{mg} \cdot \mathrm{kg}^{-1} \cdot \mathrm{d}^{-1}\right)$ and $107 \pm 4$ $\mu \mathrm{mol} \cdot \mathrm{kg}^{-1} \cdot \mathrm{h}^{-1}\left(339 \pm 13 \mathrm{mg} \cdot \mathrm{kg}^{-1} \cdot \mathrm{d}^{-1}\right)$, respectively. All infants were growing at the time of the study, with no statistically significant differences between the groups (Table 1 ).

We found plateaus in the enrichment of expiratory $\mathrm{CO}_{2}$ after $1-2 \mathrm{~h}$ of $\left[1-{ }^{1.3} \mathrm{C}\right]$ leucine infusion (Fig. 1) (coefficient of variation $3.3 \%$ ). Enrichment of urinary ammonia usually reached plateau between 12 and $30 \mathrm{~h}$ (coefficient of variation for AGA infants $8.0 \%$, for SGA infants $6.7 \%$ ), whereas urinary urea enrichment showed a plateau between 48 and $72 \mathrm{~h}$ (coefficient of variation for AGA infants 7.2\%). No significant enrichment and/or plateau of urea was found in the majority of the SGA infants (seven out of nine). Those infants had, compared with the infants who showed a plateau in urinary urea enrichment, a lower study wcight $(1.3 \pm 0.1$ versus $1.5 \pm 0.2 \mathrm{~kg}, p=0.01)$ and higher gestational age ( $32 \pm 2$ versus $30 \pm 1 \mathrm{wk}, p=$ $0.005)$, but they were also younger at the time of the study $(22 \pm 4$ versus $30 \pm 8 \mathrm{~d}, p=0.03)$ and had a lower leucine oxidation $\left(48 \pm 16\right.$ versus $71 \pm 22 \mu \mathrm{mol} \cdot \mathrm{kg}^{-1} \cdot \mathrm{h}^{-1}, p=$ $0.025)$.

Whole-body protein turnover rates ranged from 10 to 14 $\mathrm{g} \cdot \mathrm{kg}^{-1} \cdot \mathrm{d}^{-1}$, except for the rate calculated from the urinary nitrogen excretion and the enrichment of expiratory $\mathrm{CO}_{2}$ (calculation 5), which was much lower than all of the other estimations $(p<0.0001$, Table 2$)$. Whole-body protein turnover based on enrichment in $\left[{ }^{15} \mathrm{~N}\right]$ ammonia was lower than

Table 1. Clinical characteristics of the infants

\begin{tabular}{|c|c|c|}
\hline & $\begin{array}{c}\text { AGA } \\
(n=14)\end{array}$ & $\begin{array}{c}\text { SGA } \\
(n=9)\end{array}$ \\
\hline Birth wcight $(\mathrm{kg})$ & $1.2 \pm 0.2$ & $1.0 \pm 0.2$ \\
\hline Gestational age (wk) & $29 \pm 1$ & $32 \pm 2 \dagger$ \\
\hline Age at study (d) & $29 \pm 8$ & $24 \pm 6$ \\
\hline Weight at study $(\mathrm{kg})$ & $1.5 \pm 0.2$ & $1.2 \pm 0.1 \%$ \\
\hline Weight gain $\left(g \cdot k g^{\prime} \cdot d^{\prime}\right)$ & $16.3 \pm 3.1$ & $17.3 \pm 2.1$ \\
\hline Energy intake $\left(\mathrm{kcal} \cdot \mathrm{kg}^{\prime} \cdot \mathrm{d}^{-1}\right)$ & $110 \pm 10$ & $108 \pm 12$ \\
\hline Protcin intake $\left(\mathrm{g} \cdot \mathrm{kg}^{-1} \cdot \mathrm{d}^{-1}\right)$ & $3.2 \pm 0.1$ & $3.2 \pm 0.2$ \\
\hline
\end{tabular}

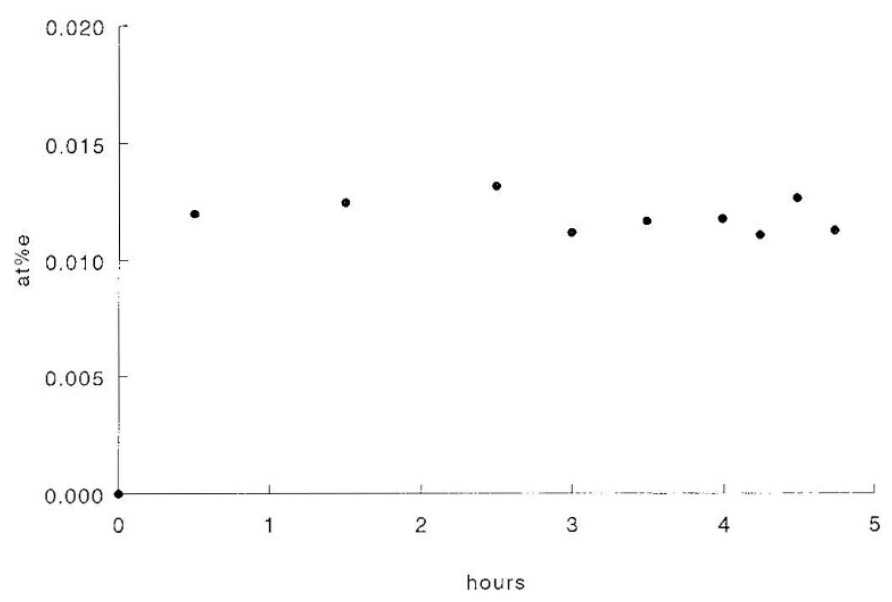

Figure 1. An example of enrichment in expiratory air after a $\left[1-{ }^{13} \mathrm{C}\right]$ leucine infusion.

whole-body protein turnover calculated using enrichment in plasma $\alpha$-KICA (Table 2) ( $p=0.024)$, both being, however, in the range of $10-14 \mathrm{~g} \cdot \mathrm{kg}^{-1} \cdot \mathrm{d}^{-1}$.

Table 3 denotes the relation between the turnover rates from the different calculations calculated for the individual patients. Only turnover rates calculated from the $\alpha$-KICA enrichment and from the harmonic average of turnovers based on enrichment of urinary ammonia and urea showed a weak positive correlation.

Leucine kinctics are shown in Table 4. We found no correlation between the nitrogen excretion and leucine oxidation $(r=0.12)$. Leucine balance was $32 \pm 22 \mu \mathrm{mol} \cdot \mathrm{kg}^{-1} \cdot \mathrm{h}^{-1}$ for AGA infants and $47 \pm 15 \mu \mathrm{mol} \cdot \mathrm{kg}^{-1} \cdot \mathrm{h}^{-1}$ for SGA infants $(p=0.13)$.

Differences in whole-body protcin turnover between AGA and SGA infants were found using only calculation 2 (enrichment $\mathrm{NH}_{3}$ ), with a higher turnover in SGA infants. SGA infants had lower nitrogen excretion rates than AGA infants (94 $\pm 18 \mathrm{mg} \cdot \mathrm{kg}^{-1} \cdot \mathrm{d}^{-1}$ SGA versus $142 \pm 42 \mathrm{mg} \cdot \mathrm{kg}^{-1} \cdot \mathrm{d}^{-1}$ AGA, $p=0.001$ ). Nitrogen balance in SGA infants was significantly higher in SGA infants compared with AGA infants $\left(416 \pm 25 \mathrm{mg} \cdot \mathrm{kg}^{-1} \cdot \mathrm{d}^{-1}\right.$ SGA infants versus $374 \pm 41$ $\mathrm{mg} \cdot \mathrm{kg}^{-1} \cdot \mathrm{d}^{-1}$ AGA infants, $p=0.003$ )

\section{DISCUSSION}

The advantage of methods based on end products is the noninvasive character of the studies. This is especially important for studies in preterm infants with a limit to the amount of blood that can be drawn for study purposes. Except for the difference between end product measurement versus direct measurement, it is also possible to make a distinction between the methods relating to the tracer used $\left(\left[{ }^{15} \mathrm{~N}\right]\right.$ glycine versus $\left[1-{ }^{13} \mathrm{C}\right]$ leucine $)$. The calculation of whole-body protein turnover from the turnover of the total amino acid pool as is done using $\left[{ }^{15} \mathrm{~N}\right]$ glycine (calculations $1-4$ ) or from the kinetics of a specific amino acid (calculations 5 and 6 ) is different. The ${ }^{15} \mathrm{~N}$ end product method assumes a labeling of the total amino acid pool by means of exchange of nitrogen between the metabolically active amino acids. The assumptions in case of calculations with the use of $\left[1-{ }^{13} \mathrm{C}\right]$ lcucine are diffcrent. Because 
Table 2. Rates of whole-body protein flux, protein synthesis, and protein breakdown estimated from different tracers and calculations

\begin{tabular}{|c|c|c|c|c|c|c|}
\hline & & AGA & & & SGA & \\
\hline & $\mathrm{Q}$ & S & B & $\mathrm{Q}$ & $S$ & $B$ \\
\hline \multicolumn{7}{|l|}{ End products } \\
\hline $2 \mathrm{NH}_{3}^{*}$ & $10.4 \pm 1.1$ & $9.5 \pm 1.2$ & $7.5 \pm 1.1$ & $12.9 \pm 2.6 \dagger$ & $12.3 \pm 2.6 \dagger$ & $10.0 \pm 2.6 \dagger$ \\
\hline 3 Arithmatic average & $11.5 \pm 1.3$ & $10.6 \pm 1.5$ & $8.6 \pm 1.3$ & & & \\
\hline 4 Harmonic average & $11.3 \pm 1.2$ & $10.4 \pm 1.4$ & $8.4 \pm 1.2$ & & & \\
\hline $5 \mathrm{CO}_{2}$ & $6.0 \pm 2.2$ & $5.1 \pm 2.0$ & $3.1 \pm 2.2$ & $4.7 \pm 1.2$ & $4.1 \pm 1.1$ & $1.8 \pm 1.1$ \\
\hline $7 \mathrm{KICA}+\mathrm{CO}_{2} *$ & $14.0 \pm 3.0$ & $11.2 \pm 2.4$ & $9.9 \pm 3.0$ & $13.4 \pm 5.2$ & $11.2 \pm 4.5$ & $9.3 \pm 5.0$ \\
\hline
\end{tabular}

All rates are given in grams of protein per kilogram per day. 1, Administration of $\left[{ }^{15} \mathrm{~N}\right]$ glycine and measurement of $\left[{ }^{15} \mathrm{~N}\right]$ urea enrichment; 2 , administration of $\left[{ }^{15} \mathrm{~N}\right]$ glycine and measurement of ${ }^{15} \mathrm{~N}$-ammonia enrichment; 3, administration of $\left[{ }^{15} \mathrm{~N}\right]$ glycine and taking an arithmetic mean of 1 and $2 ; 4$, administration of $\left[{ }^{15} \mathrm{~N}\right]$ glycine and taking a harmonic mean of 1 and $2 ; 5$, administration of $\left[1-{ }^{13} \mathrm{C}\right.$ lecucine and measuring the enrichment in cxpiratory air; 6 , administration of $\left[1-{ }^{13} \mathrm{C}\right]$ leucine and measuring the cnrichment in plasma. Synthesis and breakdown rates are obtained from the nitrogen excretion and protein intakc; 7 , administration of $\left[1-{ }^{13} \mathrm{C}\right]$ leucine and measuring the enrichment in plasma and in expiratory air. Synthesis and breakdown rates are obtained from equation 9 . Q, protein turnover; $\mathrm{S}$, protein synthesis; B, protein breakdown.

* Difference at $P<0.05$ between calculation 3 vs 6 and 7.

$\dagger$ Significant difference between AGA and SGA infants at $P<0.05$.

$¥$ Significant difference between calculation 5 and the others at $P<0.0001$.

Table 3. Relative percentage of protein turnover and correlations between protein turnover in individual patients

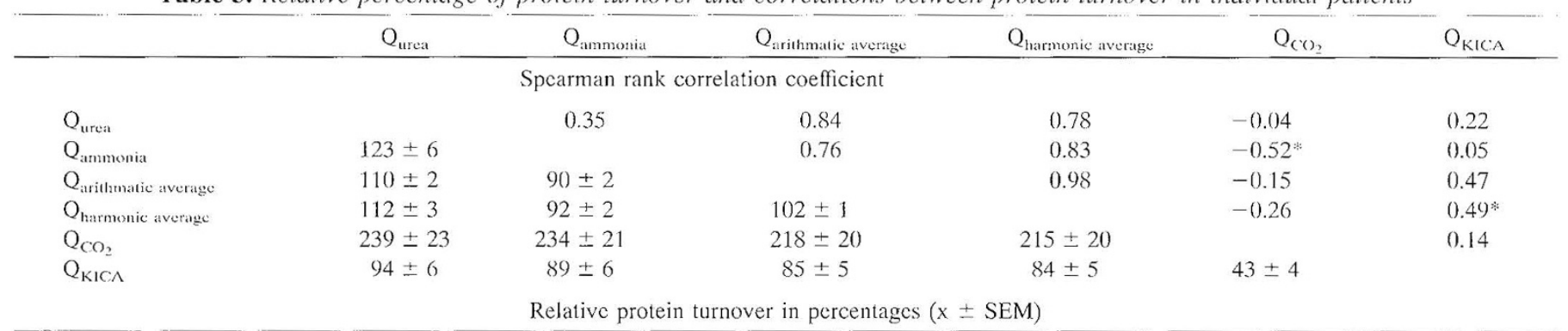

The relative percentage of protein turnover $(\mathrm{x} / \mathrm{y})$ is depicted in the left lower half of the table, the correlations between protein turnover in individual patients (Spearman) are shown in the upper right half of the table.

* Significance at $P<0.05$.

Table 4. Leucine kinetics in AGA and SGA infants

\begin{tabular}{lcc}
\cline { 3 - 3 } & AGA & SGA \\
\hline Turnover $\left(\mu \mathrm{mol} \cdot \mathrm{kg}^{-1} \cdot \mathrm{h}^{-1}\right)$ & $345 \pm 74$ & $329 \pm 127$ \\
Recovery of ${ }^{13} \mathrm{C}$ in expired air $(\%)$ & $20 \pm 4$ & $17 \pm 2$ \\
Oxidation $\left(\mu \mathrm{mol} \cdot \mathrm{kg}^{-1} \cdot \mathrm{h}^{-1}\right)$ & $70 \pm 22$ & $54 \pm 18$ \\
$\quad \begin{array}{c}\text { Nonoxidative disposal } \\
\quad\left(\mu \mathrm{mol} \cdot \mathrm{kg}^{-1} \cdot \mathrm{h}^{-1}\right)\end{array}$ & $275 \pm 60$ & $275 \pm 110$ \\
$\begin{array}{l}\text { Lcucine release from protein } \\
\left(\mu \mathrm{mol} \cdot \mathrm{kg}^{-1} \cdot \mathrm{h}^{-1}\right)\end{array}$ & $243 \pm 74$ & $228 \pm 123$ \\
\hline
\end{tabular}

Nonoxidative disposal represents protein synthesis, lcucine rclcase from protein is analogous to protein breakdown.

leucine is an essential amino acid, it is assumed that the rate of appearance of leucinc ( $\alpha$-KICA) is a reflection of release of all amino acids from body protcins, because there is no de novo synthesis of leucine. Both methods have their limitations.

Glycine. The $\left[{ }^{15} \mathrm{~N}\right]$ glycine method assumes that the total active body pool of amino acids consists of one or two metabolically active pools from which urea and ammonia are derived. The label ${ }^{15} \mathrm{~N}$ enters the pool and is assumed to be rapidly exchanged between all metabolically active amino acids. Urea and ammonia are assumed to be arising from this pool. Urea is synthesized in the liver via the urea cycle (35). Nitrogen enters this cycle by carbamoylphosphate and aspartate. Nitrogen for aspartate arises from the $\alpha$ amino group of glutamate and the nitrogen for carbamoylphosphate is derived from ammonia. The latter could be derived from the amide groups of glutamine and asparagine or by degradation reactions of serinc, threonine, histidine, glycine, and methionine. Ammonia from the bacterial decomposition of urea in the gut can also be a significant precursor. Glutamate receives its nitrogen from the majority of amino acids, but not from glycine and serine, during the following rapid conversion that is mediated by glutamate transaminasc: $\alpha$-amino acid $+\alpha$-ketoglutarate $\Leftrightarrow$ $\alpha$-keto acid + glutamate. Nitrogen in the urea moleculc could therefore be derived from many different amino acids.

Glycine and serine are readily transformed into onc another. In addition glycine may arise from threonine by a specific aldolase enzyme or from choline. However, the two last pathways are not likely to be quantitatively important (36). Glycine does not transaminate with glutamate as shown by Jackson and Golden (37) who observed no enrichment of glutamate during

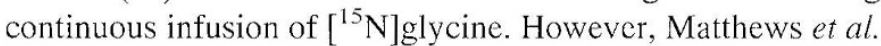
(38) showed labeled nitrogen in glutamate after $\left[{ }^{15} \mathrm{~N}\right]$ glycine administration, but a majority of the amino acids were not significantly enriched. Nitrogen (labeled) from glycine will probably not exchange to a great extent with a large group of amino acids via transamination that is considered to be a major pathway for rapid nitrogen transfer. For these reasons, doubt 
can be raised whether glycine is a suitable carrier to introduce labeled nitrogen in the metabolic nitrogen pool.

Glycine is deaminated via the glycine cleavage system, with the release of free ammonia (39). Duda and Handler (40) showed that free ammonia is considerably more rapidly incorporated into the amide position of glutamine than into any other nitrogenous component of liver. After administration of amide N-labcled glutamine, the isotope appeared only slowly in urea or glutamic acid. Other studies have shown that urinary ammonia is mainly produced from the amide $\mathrm{N}$ of glutamine in the kidney (41-43). A rapid transfer of glycine nitrogen to urinary ammonia via glutamine is therefore to be expected as was observed in both SGA and AGA infants in the present study. The question remains why we did not find enrichment of urinary urea in SGA infants.

SGA infants had lower rates of urinary nitrogen excretion, of which urea is the major component, suggesting that the urea synthesis rate was lower in this group. Regulation of the urea production might be a nitrogen conservation mechanism, occurring to a greater extent in SGA infants than in AGA infants. This hypothesis is supported by the indices of protein turnover. The efficiency of protein gain (leucine retention divided by lcucine turnover) was significantly higher in infants who showed low urea enrichments $[21 \pm 11 \%$ (low urea enrichment) versus $10 \pm 8 \%$ (plateau in urea enrichment), $p=0.03$ ]. This is in accordance with the original work of Picou and Taylor-Roberts (2), who also showed a higher protein synthesis/protein turnover $(\mathrm{S} / \mathrm{Q})$ ratio in malnourished patients, and also in accordance with Cauderay et al. (44) who showed a more efficient protein gain/protein synthesis ratio in SGA infants. In this context, SGA infants can also be considered as malnourished infants. Pencharz et al. (45), however, reported similar S/Q ratios in SGA and AGA infants. Cauderay et al. used $\left[{ }^{15} \mathrm{~N}\right]$ glycine, but reported significant urinary urea enrichments in all SGA infants in contrast to the findings in the present study. However, they administered very large amounts of $\left[{ }^{15} \mathrm{~N}\right]$ glycine, $30 \mathrm{mg} \cdot \mathrm{kg}^{-1} \cdot \mathrm{d}^{-1}$, which is no longer a tracer dose and may have resulted in an overload of glycine.

Glycine is a major component of heme and is also important for purine synthesis, whereas carbamoyl phosphate and aspartate, both urea cycle intermediates, are used for the synthesis of pyrimidines. With an increased need for those components, a large part of label could follow that pathway with a resulting low enrichment of urea. Purines are degraded to uric acid and with the degradation of pyrimidines, the amino group will be removed by transamination.

In conclusion, we can assume that ammonia and a significant part of urea nitrogen arise from very different pools of amino acids, and it is therefore not surprising that differences are obtained using both methods as has been suggested by Waterlow et al. (46). Averaging the results obtained via ammonia and urea enrichment, as is done in calculation 3 and 4 , is likely to be incorrect as well for the same reasons as discussed above. The original concept of rapid exchange of the nitrogen of glycine with other amino acids does not appear to be valid, suggesting that protein turnover as assessed by $\left[{ }^{15} \mathrm{~N}\right]$ glycinc is unlikcly to accurately represent whole-body protcin turnover.
Leucine. The original model for quantification of leucine kinetics assumes a single pool from which leucine is used for protein synthesis and into which it enters from protein breakdown. Lcucine turnover rate is calculated from the isotope dilution of the labeled leucine in plasma. The fundamental problem with this model is that the leucine tracer is infused into and sampled from plasma, whereas it is metabolized within the cells. Because lcucine is transaminated reversibly within the cell to $\alpha$-KICA, the enrichment of $\alpha$-KICA reflects the intracellular enrichment of leucine (47). Recent animal studies have shown a very good agreement of plasma $\alpha$-KICA enrichment and intracellular leucine enrichment $(48,49)$. The enrichment of $\alpha$-KICA after $\left[1-{ }^{13} \mathrm{C}\right]$ leucine infusion seems therefore a good reflection of the precursor pool for protein synthesis within the cell. Recent studies have shown that a multipool model gives the best fit for the intracellular turnover. The multipool model demands, however, many sample points and is therefore hardly feasible in premature infants. In specific circumstances the reciprocal pool model has found to be in good agreement with a seven-pool model that can be constructed from simultaneous infusion of labeled leucine and $\alpha$-KICA $(50,51)$. It is unclear whether data obtained for leucine kinetics can be extrapolated to whole-body protein turnover, synthesis, and breakdown, because leucine is predominantly metabolized in the muscle, and therefore may not be the best representative of protein metabolism in other organs. However other amino acids like tyrosine are metabolized mainly in the liver and will therefore not represent muscle protein metabolism. In general we can state that no single amino acid will represent whole-body protein turnover because whole-body protein consists of heterogenous pools of amino acids with different rates of turnover and possibly different amino acid composition.

Comparison of calculations. From the above it is clear that a comparison of methods, to decide which of the methods is "best," may not be meaningful, because calculations based on enrichment of urea, ammonia, and $\alpha$-KICA are reflections of different processes.

The end product method of estimation of whole-body protein turnover from urinary nitrogen excretion and from expiratory $\mathrm{CO}_{2}$ after $\left[1-{ }^{13} \mathrm{C}\right]$ leucine administration (calculation 5) gave results that were significantly lower compared with all the other calculations. This calculation assumes a correlation between leucine oxidation and nitrogen excretion in urine. We measured the leucine oxidation quantitatively and found that the leucine oxidation did not correlate with the urinary nitrogen excretion. Hence, this calculation is not suitable for the estimation of whole-body protein turnover in this group of patients, although it has been used in preterm infants (19) and elderly patients (18). The total amount of leucine oxidation could be influenced by the diet, because the leucine concentration of the protein in the diet exceeded the leucine tissue concentration in our study. This could have led to an increased leucine oxidation, but not to a difference in oxidation between AGA and SGA infants because both groups received the same amount of protein.

Although most group means were not significantly different, the turnover rates obtained by measurement of plasma $\alpha$-KICA 
enrichment (calculations 6 and 7) were higher than the other rates. The duration of tracer administration is much shorter compared with the duration of $\left[{ }^{15} \mathrm{~N}\right]$ glycine administration. Recycling of the tracer in the latter experiments could increase the enrichment, with a corresponding lower turnover rate. Estimation of recycling of $\left[{ }^{15} \mathrm{~N}\right]$ glycine by Cauderay et al. (44) was $20 \%$ after $72 \mathrm{~h}$ of infusion, whereas Schwenk et al. (52) calculate $30 \%$ recycling of a labeled essential amino acid after $24 \mathrm{~h}$ of infusion.

Methodology. Some methodologic questions can be raised regarding the present study. First, a plateau in KICA enrichment cannot be defined on two blood samples. However, we found it unethical to take more than three blood samples from premature infants just for study purposes. Furthermore, we found a plateau in enrichment of expiratory $\mathrm{CO}_{2}$, which means a plateau in enrichment of the precursor of $\mathrm{CO}_{2}, \mathrm{KICA}$.

Sccond, urine collection via bags might be a source of error in measuring nitrogen excretion. However, by measuring the change of weight of every diaper, it is possible to extrapolate the measured nitrogen content of the collected urine to the total urine production to calculate the total urinary nitrogen excretion. A source of error in calculated urinary nitrogen excretion would affect only the results of calculation 5 , because this calculation is dependent on nitrogen excretion for calculating protein flux. Direct measurements of tracer dilution are used in all other calculations, which makes model dependent issues more likely to explain the differences found in protein fluxes.

Route of tracer administration. In this study, we administered the tracer by the same route as the feed. Some considerations have to be made when using intragastric infusion of label. The intestinal absorption must be known. The $\left[{ }^{15} \mathrm{~N}\right] \mathrm{gly}-$ cine cxcretion in feces has been measured before and is $0.3-3 \%$ of the intake $(2,8)$. Another possible confounding factor is the uptake in the splanchnic area. With a considerable uptake of tracer and tracee in the splanchnic area, the amount of tracer that reaches the circulation is reduced. Subsequently, this amount is more easily diluted by the systemic flux, resulting in a lower enrichment. Both protein turnover and protcolysis could therefore be overestimated.

Conclusions. In SGA infants, urinary ammonia bccomes enriched after continuous administration of $\left[{ }^{15} \mathrm{~N}\right]$ glycine. Urinary urea shows hardly any enrichment, which might be due to a decreased rate of label transfer from glycinc to urea. This suggests a protein-sparing mechanism in SGA infants that is supported by a decreased nitrogen excretion and a decreased leucine oxidation found in this group of infants. Group averages for whole-body protein turnover in orally fed preterm infants ranged between 10 and $14 \mathrm{~g} \cdot \mathrm{kg}^{-1} \cdot \mathrm{d}^{-1}$, except for the calculation based upon a correlation of leucine oxidation and nitrogen excretion. Lcucine oxidation is not correlated with nitrogen excretion. We found no correlation between wholebody protein turnover measurements with $\left[{ }^{15} \mathrm{~N}\right]$ glycine or $\left[1-{ }^{13} \mathrm{C}\right]$ leucine within individual patients.

Acknowledgments. The authors thank P. J. A. M. Adan and I. H. T. Luijendijk for expert technical assistance. We are also very grateful to the nursing staff for their help in collecting the material and S. C. Kalhan for his very helpful discussions.

\section{REFERENCES}

1. Schoenheimer R, Ratner S, Rittenberg D 1939 Studies in protein metabolism: metabolic activity of body proteins investigated with $1(-)$-leucine containing two isotopes. J Biol Chem 130:703-7.32

2. Picou D, Taylor-Roberts T' 1969 The measurement of total protein synthesis and catabolism and nitrogen turnover in infants in different nutritional states and receiving different amounts of dietary protein. Clin Sci $36: 283-296$

3. Pencharz PB, Steffec WP, Cochran W, Scrimshaw NS, Rand WM, Young VR 1977 Protein metabolism in human neonates: nitrogen-balance studies, estimated obligatory losses of nitrogen and whole body turnover of nitrogen. Clin Sci Mol Med 52:485-495

4. Jackson AA, Shaw JCL, Barber A, Golden MHN 1981 Nitrogen metabolism in preterm infants fed human donor breastmilk: the possibie essentiality of glycine. Pediatr Res 15:1454-1461

5. Catzeflis C, Schutz Y, Micheli JL, Welsch C, Amaud MJ, Jequier E: 1985 Whole body protein synthesis and energy expenditure in very low birth weight infants. Pediatr Res 19:679-687

6. Duffy B, P'enchary P 1986 The efiect of feeding route (IV or oral) on the protein metabolism of the neonate. Am J Clin Nutr 43:108-111

7. Duffy B, Pencharz P 1986 The effects of surgery on the nitrogen metabolism of parenterally fed human neonates. Pediatr Res 20:32-35

8. Plath C, Heine W. Wulzke KD, Krienke L. Töwe J, Massute G, Windischmann C $1987^{15} \mathrm{~N}$ tracer kinetic studies on the validity of various ${ }^{15} \mathrm{~N}$ tracer substances for determining whole-body protein parameters in very small preterm infants. J Pediatr Gastroenterol Nutr 6:400-408

9. Stack T, Reeds PJ, Preston T; Hay S, LLoyd DJ, Aggett PJ $1989{ }^{15} \mathrm{~N}$ tracer studies of protein metabolism in low birth weight preterm infants: a comparison of ${ }^{15} \mathrm{~N}$ glycinc and ${ }^{15} \mathrm{~N}$ yeast protein hydrolysate and of human milk- and formula-fed babies. Pediatr Res 25:167-172

10. Van Lingen RA, Van Goudoever JB, Luijendijk IIIT, Wattimena JLD, Sauer PJJ 1992 Effects of early amino acid administration during total parenteral nutrition on protein metabolism in pre-term infants. Clin Sci 82:199-20)3

11. DeBenoist B, Abdulraz measurement of whole body protein turnover in the pre-term infant with intragastric infusion of $\mathrm{s}-\left[1-{ }^{1.3} \mathrm{C}\right]$ leucine and sampling of urinary leucine pool. Clin Sci $66: 155-$ 164

12. Kandil H, Darwish O, Hammad S, Zagloul N, Halliday D, Millward DJ 1991 Nitrogen balance and protein turnover during growth failure in newly-born low birth weight infants. Am J Clin Nutr 53:1411-1417

13. Beaufrere B, Putel G, Pachiaudi C, Salle B 1990 Whole body protein turnover measured with ${ }^{13} \mathrm{C}$-leucine and energy expenditure in preterm infants. Pediatr Res 28: 147-152

14. Mitton SG, Calder AG, Garlick PJ 1991 Protein turnover rates in sick premature neonates during the first few days of life. Pediatr Res 30:418-422

15. Mitton SG, Garlick PJ 1992 Changes in protein turnover after the introduction of parenteral nutrition in premature infants: comparison of breast milk and egg proteinbased amino acid solutions. Pediatr Res 32:447-454

16. Denne SC, Karn CA, Liechty EA 1992 Leucine kinctics after a briel fast and in response to feeding in premature infants. Am J Clin Nutr 56:899-9044

17. Beaufrere B, Fournier V, Salle B, Putet G 1992 Leucine kinetics in fed low-birthweight infants: importance of splanchnic tissues. Am J Physiol 263: E214-E220

18. Golden MHN, Waterlow JC 1977 Total protein synthesis in elderly people: a comparison of results with $\left[{ }^{15} \mathrm{~N}\right] \mathrm{glycine}$ and $\left[{ }^{1+} \mathrm{C}\right.$ leucine. Clin Sci Mol Med 53:277-

19. Pencharz P, Beesley J. Sauer P, Van Aerde J, Canagayar U, Renner J, McVey M, Wesson D, Swyer P 1989 A comparison of the estimates of whole-body protein turnover in parenterally fed neonates obtained using three different end products. Can J Physiol Pharmacol 67:624-628

20. Wutzke KD, llcine W, Plath C, Müller M, Uhlemannn M 1992 Whole-body proten parameters in premature infants: a comparison of different ${ }^{15} \mathrm{~N}$ tracer substances and different methods. Pediatr Res 31:95-101

21. Usher RH, Mclean F 1969) Intrauterine growth of live-born caucasian infants at sea level: standards obtained from measurements in 7 dimensions of infants born between 25 and 44 wk of gestation. J Pediatr 74:901-910

22. Ballard JL, Khoury JC, Wedig K. Wang L, Eilers-Walsman BL, Lipp R 199 I New Ballard score, expanded to include extremely premature infants. J Pediatr 119:417423

23. Darling P, Lepage G, Tremblay P, Collet S, Kien LC, Roy CC 1985 Protein quality and quantity in preterm infants receiving the same encroy intake. $A m \mathrm{~J}$ Dis Child $139: 186-190$

24. Shenai JP, Reynolds JW, Babson SG 1980 Nutritional balance studies in very-lowbirth-weight infants: enhanced nutrient retention rates by an experimental formula. Pediatrics 66:233-238

25. Huston RK, Reynolds JW, Jensen C, Buist NRM 1983 Nutrient and mineral retention and vitamin $\mathrm{D}$ absorption in low-birth-weight infants: effect of medium-chain triglycerides. Pediatrics 72:44-48

26. Sulkers EJ, Van Goudoever JB, Leunisse C, Wattimena JLD, Sauer PJJ 1992 Comparison of two preterm formulas with and without addition of medium-chain triglycerides (MCTs). I. Effects on nitrogen and fat balance and body composition. $J$ Pediatr Galstroenterol Nutr 15:34-41

27. Lafeber HN, Sulkers EJ, Chapman TE, Sauer PJJ 1990 Glucose production and oxidation in preterm infants during total parenteral nutrition. Pediatr Res 28:153-157

28. Ford GC, Cheng KN, Halliday D 1985 Analysis of $\left[1-{ }^{13} \mathrm{C}\right]$ leucine and $\left[{ }^{13} \mathrm{C}\right] \mathrm{KICA}$ in plasma by capillary gas chromatography/mass spectrometry in protein turnover studies. Biomed Mass Spectrom 12:432-436 
29. Fern EB, Garlick PJ, Waterlow JC 1985 The concept of the single body pool of metabolic nitrogen in determining the rate of whole-body nitrogen turnover. Hum Nutr Clin Nutr 39c: 85:99

30. Fern EB, Garlick PJ, Waterlow JC 1985 Apparent compartmentation of body nitrogen in one human subject: its consequences in measuring the rate of whole-body protein synthesis with ${ }^{15} \mathrm{~N}$. Clin Sci 68:271-282

31. Van Aerde JEE, Saucr PJJ, Pencharz PB, Canagarayar U, Beesley J, Smith JM, Swyer PR 1985 The effect of cnergy intake and expenditure on the recovery of ${ }^{13} \mathrm{CO}_{2}$ in the parenterally fed neonate during a 4-hour primed constant infusion of $\mathrm{NaH}^{13} \mathrm{CO}_{3}$. Pediatr Res 19:806-810

32. Watcrlow JC, Garlick PJ, Millward DJ 1978 Protein Turnover in Mammalian Tissues and in the Whole Body. Elsevier North-Holland, Amsterdam

33. Matthews DE, Schwartz HP, Yang RD, Motil KJ, Young VR, Bier DM 1982 Relationship of plasma leucine and $\alpha$-ketoisocaproate during a $1-\left[1-{ }^{13} \mathrm{C}\right]$ leucine infusion in man: a method for measuring human intracellular leucine tracer enrichment. Metabolism 31:1105

34. Schwenk WF, Beaufrere B, Haymond MW 1985 Use of reciprocal pool specific activities to model leucine metabolism in humans. Am J Physiol 249:E646-E650

35. Krebs HA, Hems R, Lund P 1973 Some regulatory mechanisms in the synthesis of urea in the mammalian liver. Adv Enzyme Regul 11:361-377

36. Neuberger A 1961 Aspects of metabolism of glycine and porphyrins. Biochem J 78:1-10

37. Jackson AA, Golden MHN $1980\left[{ }^{15} \mathrm{~N}\right]$ Glycine metabolism in normal man: the metabolic $\alpha$-amino-nitrogen pool. Clin Sci 58:517-522

38. Matthews DE, Conway JM, Young VR, Bier DM 1981 Glycine nitrogen metabolism in man. Metabolism 30:886-893

39. Kikuchi G 1971 The glycine cleavage system: composition, reaction mechanism and physiological significance. Moll Ccll Biochem 1:169-187

40. Duda GD, Handler P 1958 Kinetics of ammonia metabolism in vivo. J Biol Chem $234: 303-314$
41. Pitts RF, Pilkington LA 1966 The relation between plasma concentrations of glutamine and glycine and utilisation of their nitrogens as sources of urinary ammonia. Clin Invest 45:86-93

42. Pitts RF 1974 Physiology of the Kidncy and Body Fluids, 3rd Ed, Year Book, Chicago, p 226

43. Owen EE, Robinson RR 1963 Amino acid extraction and ammonia metabolism by the human kidney during prolonged administration of ammonium chloride. J Clin Invest $42: 263-276$

44. Cauderay M, Schutz Y, Micheli JL, Calame A, Jequier E 1988 Energy-nitrogen balances and protein turnover in small and appropriate for gestational age low birthweight infants. Eur J Clin Nutr 42:125-136

45. Pencharz PB, Masson M, Desgranges F, Papageorgiou A. 1981 Total-body protein turnover in human premature neonates: effects of birth weight, intra-uterine nutritional status and dict. Clin Sci 61:207-215

46. Waterlow JC, Golden MHN, Garlick PJ 1978 Protein turnover in man measured with ${ }^{15} \mathrm{~N}$ : comparison of end products and dose regimes. Am J Physiol 4:E165-E174

47. Nissen S, Haymond MW 1981 Effect of fasting on flux and interconversion of lcucine and $\alpha$-ketoisocaproate in vivo. Am J Physiol 241:E72-E75

48. Laurent BC, Moldawer LL, Young VR, Bistrian BR, Blackburn GL 1984 Whole body leucine and muscle protein kinetics in rats varying protein intakes. Am $\mathbf{J}$ Physio 246:E444-E451

49. Vazquez JA, Paul HS, Abidi SA 1986 Relation between plasma and tissue parameters of Ieucine metabolism in fed and starved rats. Am J Physiol 250:E615-E621

50. Matthews DE, Cobelli C 1991 Leucine metabolism in man: lessons from modelling. J Parenter Entcral Nutr 15:86S-89S

51. Cobelli C, Saccomani MP, Tessari P, Biolo G, Luzi L, Matthews DE 1991 Compart ment model of lcucine kinetics in humans. Am J Physiol 261:E539-E550

52. Schwenk WF, Tsalikian E, Beaufrere B, Haymond MW 1985 Recycling of an amino acid label with prolonged isotope infusion: implications for kinetic studies. Am J Physiol 248:E482-E487 